\title{
Dendritic Cell Subsets in Asthma: Impaired Tolerance or Exaggerated Inflammation?
}

\author{
Heleen Vroman, Rudi W. Hendriks and Mirjam Kool \\ Department of Pulmonary Medicine, Erasmus MC, Rotterdam, Netherlands
}

Asthma is a prevalent chronic heterogeneous inflammatory disease of the airways, leading to reversible airway obstruction, in which various inflammatory responses can be observed. Mild to moderate asthma patients often present with a Th2-mediated eosinophilic inflammation whereas in severe asthma patients, a Th17-associated neutrophilic or combined Th2 and Th17-mediated eosinophilic/neutrophilic inflammation is observed. The differentiation of these effector Th2 and Th17-cells is induced by allergen-exposed dendritic cells (DCs) that migrate toward the lung draining lymph node. The DC lin-

OPEN ACCESS

Edited by: Jixin Zhong,

Case Western Reserve University, United States

Reviewed by:

Shanzhong Gong,

University of Texas at Austin,

United States

Fei Teng,

Weill Cornell Medical College,

United States

Xiaojing Yue,

La Jolla Institute for Allergy and Immunology, United States

*Correspondence: Mirjam Kool m.koo/@erasmusmc.nl

Specialty section:

This article was submitted to Inflammation,

a section of the journal

Frontiers in Immunology

Received: 24 May 2017

Accepted: 24 July 2017

Published: 09 August 2017

Citation:

Vroman $\mathrm{H}$, Hendriks $R W$ and Kool $M$ (2017) Dendritic Cell Subsets in Asthma: Impaired Tolerance or Exaggerated Inflammation?

Front. Immunol. 8:941. doi: 10.3389/fimmu.2017.00941 eage comprises conventional DCs (cDCs) and plasmacytoid DCs (pDCs), of which the $\mathrm{cDC}$ lineage consists of type $1 \mathrm{cDCs}(\mathrm{cDC} 1 \mathrm{~s})$ and $\mathrm{cDC} 2 \mathrm{~s}$. During inflammation, also monocytes can differentiate into so-called monocyte-derived DCs (moDCs). These DC subsets differ both in ontogeny, localization, and in their functional properties. New identification tools and the availability of transgenic mice targeting specific DC subsets enable the investigation of how these different DC subsets contribute to or suppress asthma pathogenesis. In this review, we will discuss mechanisms used by different DC subsets to elicit or hamper the pathogenesis of both Th2-mediated eosinophilic asthma and more severe Th17-mediated neutrophilic inflammation.

Keywords: asthma, dendritic cells, Th2 cells, Th17 cells, airway inflammation

Allergen-activated dendritic cells (DCs) are essential not only for the induction of Thelper (Th)-cell differentiation from naïve T-cells in the mediastinal lymph node (MLN) but also to drive pulmonary inflammation during continuous allergen exposure (1). Lung DCs are a heterogeneous cell population that contains two types of conventional DCs (cDCs), e.g., cDCs type 1 (cDC1s) cDC2s. Next to cDCs, the lungs also contain plasmacytoid DCs (pDCs) and under inflammatory conditions, monocyte-derived DCs (moDCs) (2-4). DCs can become activated by allergen exposure and by cytokines secreted by the airway epithelium $(5,6)$. Activation of DCs requires induction of

Abbreviations: AHR, airway hyperresponsiveness; BAL, bronchoalveolar lavage; BATF3, basic leucine zipper ATF-like transcription factor 3; $\mathrm{BM}$, bone marrow; $\mathrm{C}$, complement; $\mathrm{CCL}$, chemokine ligand; $\mathrm{CCR}$, chemokine receptor; $\mathrm{CDC}$, conventional dendritic cell; CDP, common DC progenitor; cMoP, common monocyte progenitors; CSF-1, colony-stimulating factor 1; DC, dendritic cell; ID-2, DNA-binding protein inhibitor 2; Der p1, Dermatophagoides pteronyssinus antigen P1; DTR, diphtheria toxin; Flt3L, FMS-like tyrosine kinase 3 ligand; GM-CSF, granulocyte macrophage colony-stimulating factor; HDM, house dust mite; HLA-DR, human leukocyte antigen-D; HSC, hematopoietic stem cell; ICOSL, inducible T-cell costimulator ligand; ID2, inhibitor of DNA binding 2; IFN- $\alpha$, interferon alpha; IL, interleukin; IRF, interferon regulatory factor; MDP, macrophage DC progenitor; MLN, mediastinal lymph node; mDCs, myeloid DCs; moDC, monocyte-derived DC; OVA, ovalbumin; OX-40L, OX-40 ligand; PAR-2, protease-activated receptor 2; pDC, plasmacytoid dendritic cell; PD-L1, programmed death-ligand 1; $\operatorname{PPAR} \gamma$, peroxisome proliferator-activated receptor gamma; PU.1, hematopoietic transcription factor PU.1; RA, retinoic acid; RALDH, retinal dehydrogenase; RBPJ, recombination signal-binding protein 1 for J-Kappa; RELB, v-rel avian reticuloendotheliosis viral oncogene homolog B; STAT3, signal transducer and activator of transcription 3; Th, thelper; TLR, toll like receptor; TNFAIP3, tumor necrosis factor alpha interacting protein 3; Treg, regulatory T cell; TSLP, thymic stromal lymphopoietin. 
the pro-inflammatory transcription factor NF- $\kappa \mathrm{B}$, which can be negatively regulated by various proteins including the deubiquitinating enzyme tumor necrosis factor alpha interacting protein 3/A20 (7).

\section{ONTOGENY}

Dendritic cells originate from hematopoietic stem cells (HSCs) in the bone marrow (BM). These HSCs differentiate into the macrophage DC progenitors (MDPs) (8), which give rise to common monocyte progenitors (cMoPs) and common DC progenitors (CDPs) (Figure 1). Whether CDPs also develop without the intermediate MDP stage is currently unknown. CDPs give rise to pre-cDCs and $\mathrm{pDCs}(9)$. BM pre-cDCs contain pre$\mathrm{cDC} 1 \mathrm{~s}$ and pre-cDC2s that are committed to $\mathrm{cDC} 1$ and $\mathrm{cDC} 2$ development. This indicates that the decision to become cDC1s or $\mathrm{CDC} 2 \mathrm{~s}$ already occurs in the BM and not in the periphery $(10,11)$. MoDCs develop from cMoPs $(12,13)$ (Figure 1).

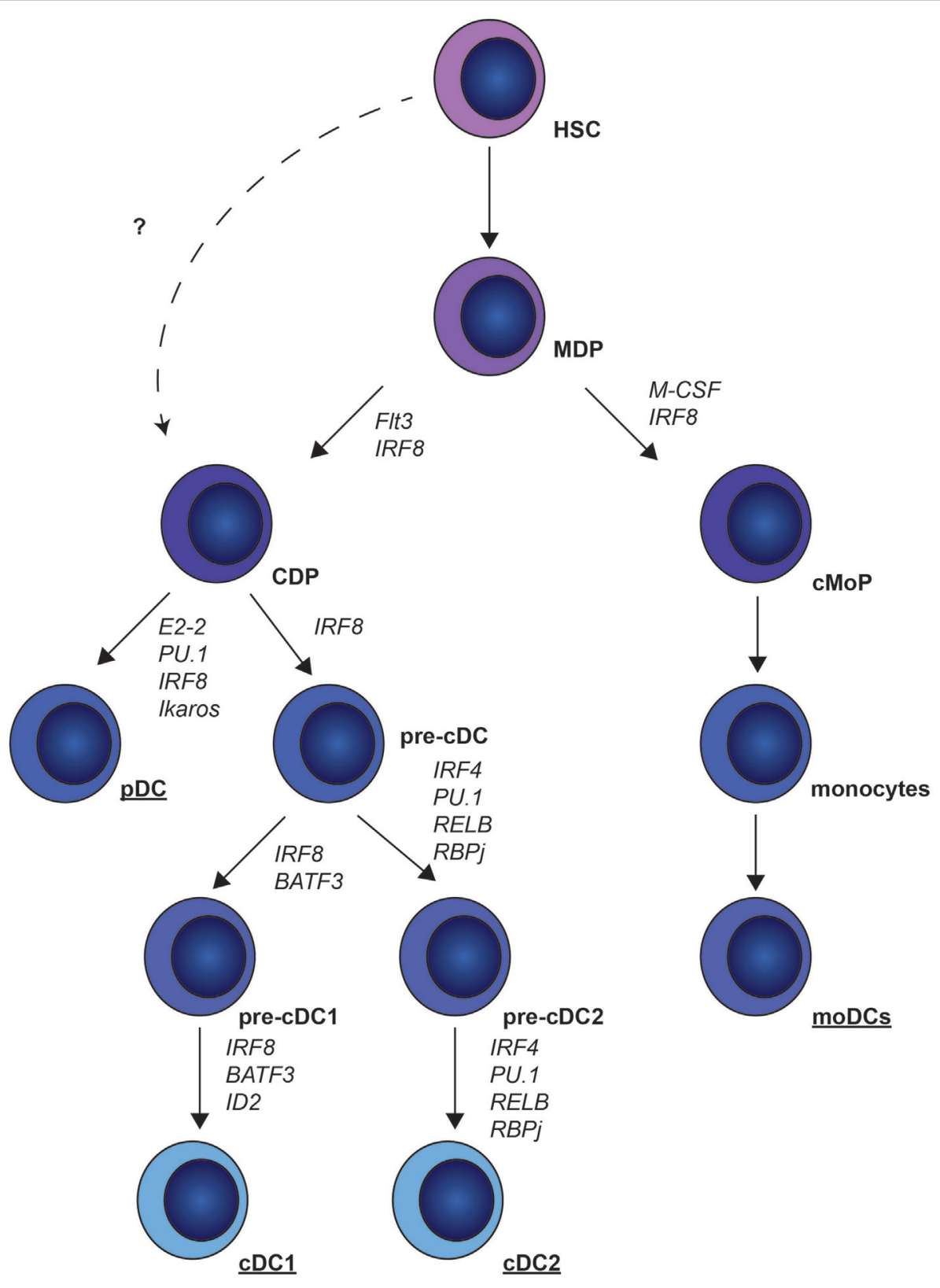

FIGURE 1 | Murine dendritic cell (DC) ontogeny. Common DC precursors (CDP) and common monocytic progenitors (cMoP) develop from myeloid-derived precursors (MDP). CDPs differentiate into plasmacytoid DCs (pDCs) under the control of E2-2, PU.1, interferon regulatory factor (IRF)8 and Ikaros, or preconventional DCs (CDCs) under the control of IRF8. Pre-cDCs give rise to pre-cDC1 and pre-cDC2, which finally differentiate into cDC1s and cDC2s. cMoPs give rise to monocytes that can further differentiate into monocyte-derived DCs (moDCs). 


\section{LOCATION OF PULMONARY DC SUBSETS}

Because pulmonary DC numbers are low and until recently multiple markers were needed to specify DC subsets, the number of studies that investigated the location of pulmonary DC subsets during steady state is limited. It is known that $\mathrm{CDC} 1 \mathrm{~s}$ are located in close proximity of the airway epithelium, whereby their expression of CD103 (alpha integrin) and beta7 integrin (Figure 2A) enables interaction with E-cadherin expressed by epithelial cells. Compared to other DC subsets, cDC1s highly express tight junction proteins, which facilitate the sampling of antigen by extending their dendrites into the airway lumen. $\mathrm{CDC} 1 \mathrm{~s}$ are also found in the proximity of vascular endothelial cells (14). Most studies that investigated CDC2 localization used CD11b (14-16); however, $\mathrm{CD} 1 \mathrm{~b}$ is not exclusively expressed by $\mathrm{cDC} 2 \mathrm{~s}$ and is also highly expressed by moDCs (1). A recent study could distinguish moDCs and cDCs by crossing MacBlue mice (Csflr-ECFP ${ }^{\mathrm{tg} /+}$ ) to Itgax-YFP or $\mathrm{C} x 3 \mathrm{cr} 1^{\mathrm{ffp} /+}$ mice, in which cDCs express YFP, using Itgax-YFP mice and monocytes/macrophages express GFP, using $\mathrm{C} \times 3 \mathrm{cr} 1^{\mathrm{gfp} /+}$ mice. This study indicated that $\mathrm{CDCs}$ are located near the large airways, whereas monocytes and alveolar macrophages are localized in the alveolar space (17). Using MacBlue mice, in situ traveling of monocytes and monocyte-derived cells in the lungs was investigated, revealing that monocyte-derived cells are located at the interface of blood vessels and the airways $(17,18)$. During steady state, the majority of pulmonary pDCs are located in the alveolar interstitium $(14,19)$; however, pDCs are also found in pulmonary infiltrates in an ovalbumin (OVA)-mediated asthma model (19).

Currently, investigating the localization of DC subsets can be performed with fewer markers, since Guilliams et al. showed that expressions of interferon regulatory factor (IRF) 4 and IRF8 are exclusive for $\mathrm{CDC} 2 \mathrm{~s}$ and $\mathrm{CDC} 1 \mathrm{~s}$, respectively, across different organs and species (3). Combining these markers with a universal DC marker such as CD11c should visualize $\mathrm{CDC}$ subsets and ease localization studies.

\section{MURINE CONVENTIONAL TYPE 1 DCs}

\section{Development of CDC1}

CDC1 development is highly dependent on the transcription factor IRF8, as IRF8 drives DC precursor generation (11) and development of pre-cDCs in the BM, and promotes survival of terminally differentiated cDC1s (20). Basic leucine zipper ATFlike transcription factor 3 (BATF3) is implicated in cDC development (21), whereas inhibitor of DNA binding 2 drives terminal differentiation of cDC1s (22) (Figure 1). Ontogeny of cDC1s is regulated by cytokines, as FMS-like tyrosine kinase 3 ligand (Flt3L)-deficient mice completely lack cDC1s in the lungs $(1,23)$.

\section{Function of cDC1s in Asthma}

$\mathrm{cDC1s}$ are well appreciated for their superior cross-presentation of antigens to $\mathrm{CD}^{+} \mathrm{T}$-cells, essential for induction of virusspecific $\mathrm{CD}^{+}$T-cells and antitumor immune responses $(21,24,25)$. However, cDC1s have an inferior capacity to take up allergens compared to other DC subsets (1). Whether $\mathrm{CDC1s}$ are also implicated in Th2 skewing in response to allergen exposure remains controversial, as cDC1s are reported to promote, inhibit, or be redundant for Th2 immune responses $(1,26,27)$. These differences may be explained by the allergen used, amount of allergen, or the mouse strain used to deplete cDC1s. Besides promoting $\mathrm{CD}^{+} \mathrm{T}$-cell responses, $\mathrm{cDC} 1 \mathrm{~s}$ are often associated with a tolerogenic function. $\mathrm{cDC} 1 \mathrm{~s}$ can induce differentiation of Tregs upon house dust mite (HDM) exposure through induction of retinoic acid (RA) and peroxisome proliferator-activated receptor gamma $(\operatorname{PPAR} \gamma)(26,28)$ (Figure 2A). During OVA or HDM-mediated airway inflammation (29) and helminth infections (30), cDC1s can limit Th2 inflammatory responses, emphasizing their tolerogenic potential. Anti-inflammatory properties of Helicobacter pylori treatment, which dampens allergic airway disease also depend on CDC1s (31). Furthermore, CD103-deficient mice exposed to an OVA-mediated asthma protocol containing five OVA aerosol challenges developed a more pronounced eosinophilic inflammation indicating their tolerogenic role during Th2-mediated immune responses (29). In contrast, $\mathrm{CD}_{103^{--}}$mice that received only a single OVA challenge had decreased eosinophilic inflammation, arguing against the tolerogenic properties of $\mathrm{CDC} 1 \mathrm{~s}$. Absence of CD103 did not affect DC migration, but decreased the percentage of allergenloaded migratory DCs in the MLN (32). Because CD103 can be expressed on both T-cells and cDC1s (33), it is hard to determine which effects are caused by the DCs. However, it is conceivable that $\mathrm{CDC} 1 \mathrm{~s}$ are essential for allergen uptake at low antigen concentrations. This could explain the decrease in allergen-loaded DCs and the absence of Th2-cell immune responses with only a single OVA challenge. By increasing the allergen exposures, absence of $\mathrm{cDC} 1 \mathrm{~s}$ can be overcome by protease activity or passive leakage, enabling other DC subsets to access the allergens and migrate toward the MLN.

In addition to their capabilities to suppress Th2-cell differentiation, cDC1s also control Th17 immune responses upon Aspergillus infections through secretion of interleukin (IL)-2 (34), indicating that $\mathrm{CDC} 1 \mathrm{~s}$ maintain homeostasis in the airways. Furthermore, $\mathrm{CDC1}$ s are also important for the removal of apoptotic cells, because resolution of airway inflammation is reduced in CD103-deficient mice (29), and CDC1s have been shown to remove apoptotic cells (35).

As it was described that pulmonary $\mathrm{cDC} 1 \mathrm{~s}$ express Langerin (14), some studies that investigated pulmonary $\mathrm{CDC} 1$ function used Langerin-diphtheria toxin (DTR) mice to specifically deplete pulmonary cDC1s (1). However, flow cytometric analysis showed that only a minority of the pulmonary $\mathrm{cDC} 1 \mathrm{~s}$ expressed Langerin (36), indicating heterogeneity within the pulmonary cDC1 population.

\section{MURINE CONVENTIONAL TYPE 2 DCs}

\section{Development of $\mathrm{CDC2}$}

In contrast to knowledge on $\mathrm{cDC1}$ development, the transcriptional control of $\mathrm{CDC} 2 \mathrm{~s}$ is not well characterized. Differentiation of $\mathrm{CDC} 2 \mathrm{~s}$ from pre-cDCs is regulated by v-rel avian reticuloendotheliosis viral oncogene homolog B (37), PU.1 (38), recombination 


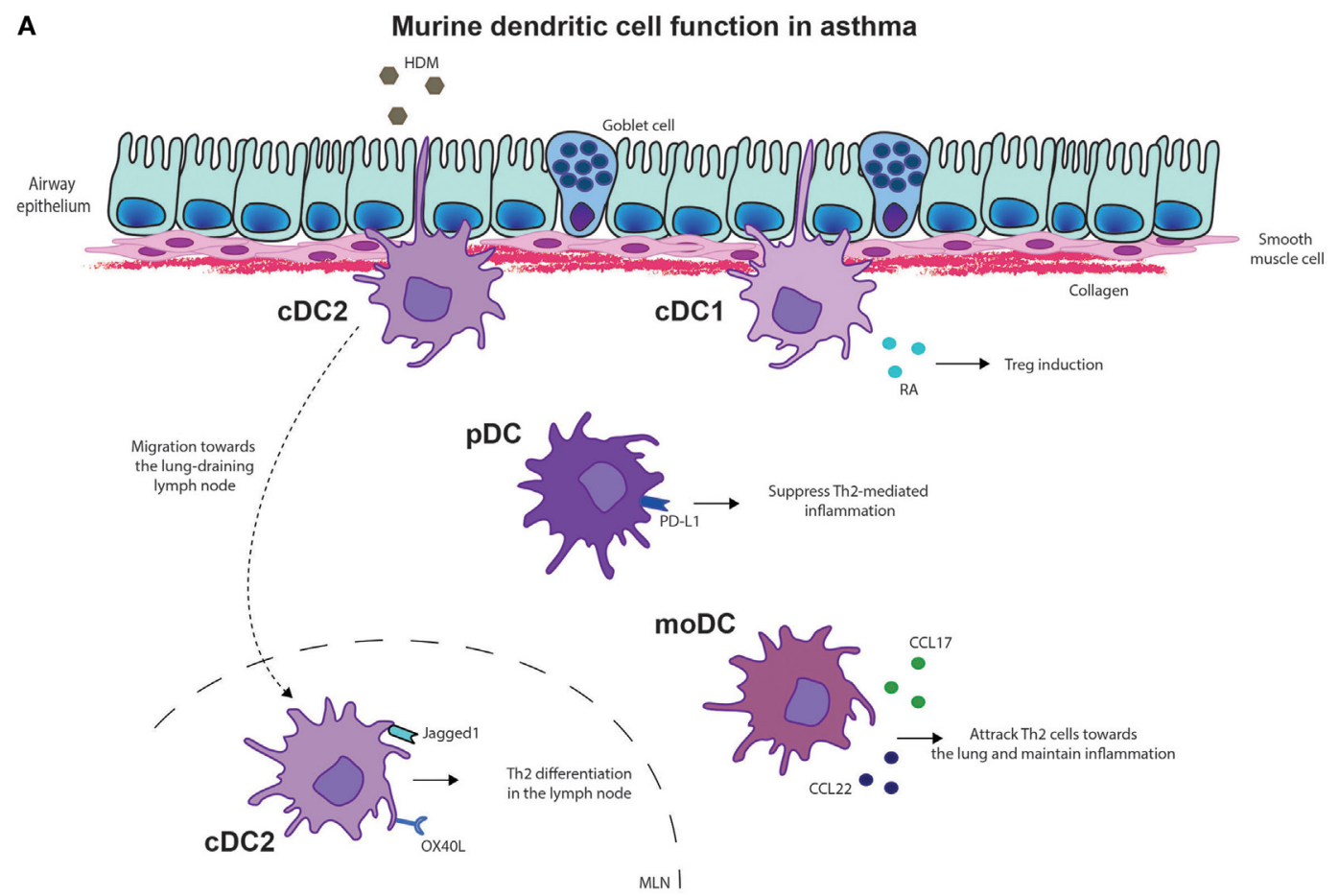

B
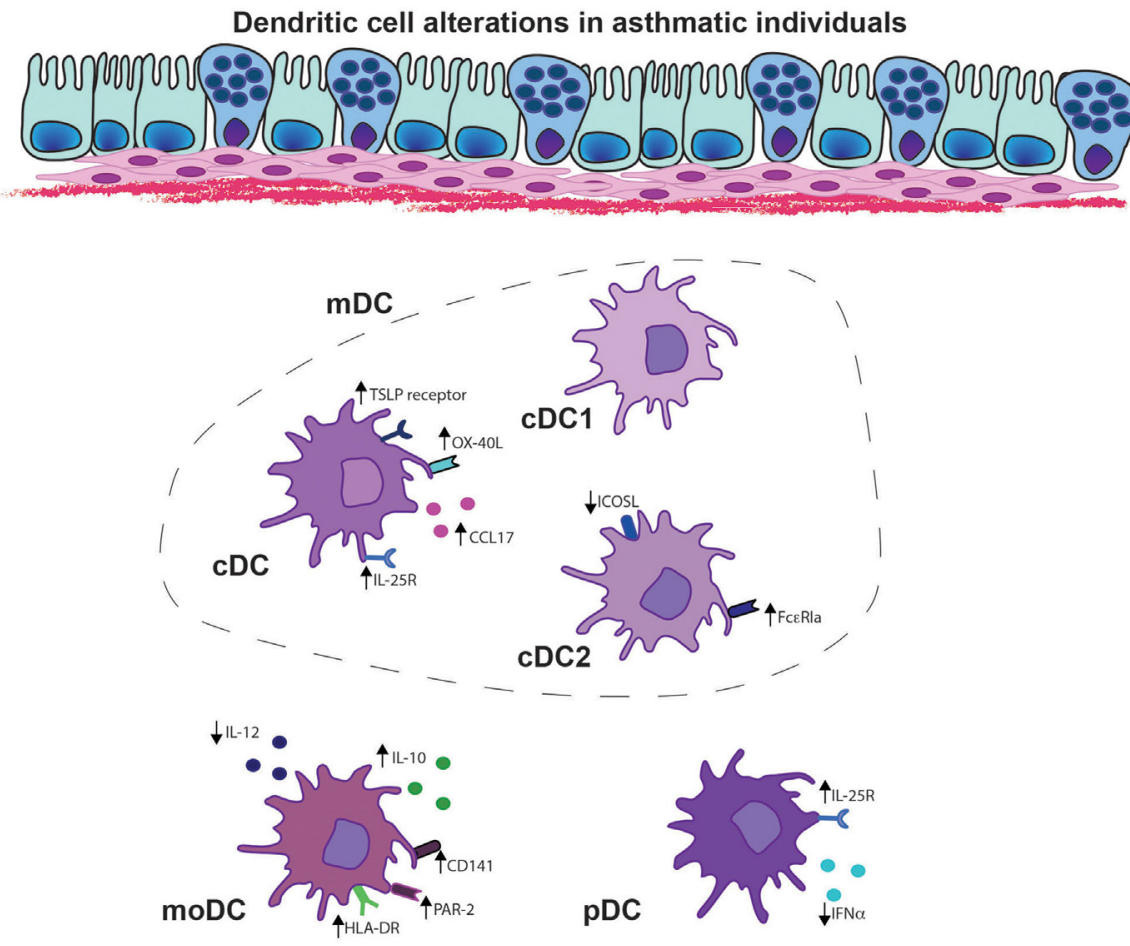

FIGURE 2 | Dendritic cell (DC) functions in asthma. (A) Murine DC functions in asthma. Type 2 cDCs are essential for the migration and induction of differentiation of Th2 cells in the lung draining lymph node upon allergen exposure. Monocyte-derived DCs (MoDCs) are important for the chemotaxis of effector Th2 cells toward the lungs by secretion of chemokines CCL17 and CCL22. In asthmatic disease, plasmacytoid DCs (pDCs) suppress Th2-mediated inflammation via programmed death-ligand 1 (PD-L1) expression, whereas CDC1s induce regulatory T cells (Tregs) via expression of retinoic acid (RA). (B) DC alterations in asthmatic individuals. Conventional DCs, including both CDC1s and CDC2s of asthma patients display higher levels of interleukin (IL)-25R, thymic stromal lymphopoietin (TSLP) receptor, OX-40 ligand (OX-4OL), and secretion of CCL17. Especially inducible T-cell costimulator ligand (ICOSL) expression in CDC2s of asthmatics is reduced whereas FceRla expression is increased in asthmatics that display a Th2 high phenotype. MoDCs of asthmatics display increased expression of human leukocyte antigen-D (HLA-DR), CD141 and protease-activated receptor 2 (PAR-2), and the anti-inflammatory cytokine IL-10, whereas IL-12 production is reduced. pDCs of asthmatics show increased expression of the IL-25R, whereas interferon alpha (IFN- $\alpha$ ) secretion was reduced. 
signal-binding protein 1 for J-Kappa (39-41), and IRF4 (42-44). However, it is unknown during which cDC2 developmental stage these transcription factors are important (Figure 1). Also, the role of the cytokine Flt3L in cDC2 development is controversial, as it has been reported that $\mathrm{CDC} 2$ development is both dependent (1) and independent (23) of Flt3L. These differences are likely caused by different methods to distinguish cDC2s from moDCs, leading to $\mathrm{CDC} 2$ fractions containing moDCs that develop independent of Flt3L (1). The newly proposed universal gating strategy using IRF4 and IRF8 (3) makes the distinction between DC subsets easier and will help future studies investigating the role of specific transcription factors or cytokines in the development of DC subsets.

\section{Function of cDC2s in Asthma}

cDC2s can take up allergen very efficiently $(1,45)$, migrate well to the MLN, and induce proper T cell proliferation (1) (Figure 2A). cDC2s are essential for the induction of Th2-cell differentiation in allergen-exposed lungs $(1,45,46)$ and possess the capability to induce Th17-cell differentiation in the gut $(42,47)$. In an HDMmediated asthma model, cDC2s induced both Th2 and Th17 differentiation (48). HDM can be recognized by various innate receptors on the cell membrane of DCs, including C-type lectin receptors, such as Dectin-2 (49). Differentiation of both HDMmediated Th2 and Th17 is dependent on Dectin-2-mediated recognition and/or allergen uptake, as both Th2 and Th17 cytokines are reduced in T-cells of Dectin-2-deficient mice (48). cDC2-deficient mice through IRF4 deficiency have reduced Th2 immune responses in the airways upon sensitization in the airways (50) or in the skin (51). Similarly, no eosinophilic inflammation or Th2 differentiation was induced in mice in which IRF4 was depleted in mature DCs, using a different CD11cCre, which did not affect cDC2 cell development (52). This indicates the importance of cDC2s for the induction of Th2 differentiation. Dectin-1 expression on DCs appears to be important for migration, as Dectin-1-deficient cDC2s display lower levels of CCR7, and have lower numbers of migratory cDC2s in the MLN. Furthermore, Dectin- $1^{-/-}$mice did not develop eosinophilic inflammation, nor did they show induction of Th2 or Th17 cytokines in an HDM-mediated asthma model (53). These findings indicate that Dectin-1 is required for the induction of chemokines and chemokine receptors on $\mathrm{cDC} 2 \mathrm{~s}$, enabling migration and T-cell differentiation. cDC2s exclusively express the TNF-superfamily member OX-40 ligand (OX-40L) (54), essential for Th2 cell differentiation, indicating the importance of cDC2s for Th2 differentiation (Figure 2A). In neonatal mice, HDM-induced IL-33 production suppressed IL-12p35 expression and induced OX-40L in cDC2s, driving Th2 differentiation (55).

\section{MURINE moDCs}

\section{Development of moDCs}

As their name implicates and stated above, moDCs derive from monocytes. There are two types of monocytes, Ly6C $\mathrm{C}^{\text {hi }}$ and Ly6Clow monocytes (56). Ly6C hi monocytes migrate toward inflammatory sites and give rise to Ly6C ${ }^{\text {hi }}$ moDCs, Ly6C ${ }^{\text {low }}$ moDCs (57), and Ly6C ${ }^{\text {low }}$ monocytes (58). MoDCs downregulate Ly6C upon differentiation from monocytes (1). Ly6 $6 \mathrm{C}^{\text {low }}$ monocytes patrol the vasculature $(56,59)$ and differentiate into more long-lived Ly6C low moDCs (57). It is suggested that monocytes or moDCs can serve as cDC precursors, in which $\mathrm{cDC} 1 \mathrm{~s}$ arise from $\mathrm{Ly} 6 \mathrm{C}^{\text {hi }} \mathrm{CCR} 2^{\text {hi }}$ monocytes, and cDC2s develop from Ly6 $6 \mathrm{C}^{\text {low }} \mathrm{CCR} 2^{\text {low }}$ monocytes (60).

\section{Function of moDCs in Asthma}

After a primary high dose of HDM in the airways, moDCs accumulate within $48 \mathrm{~h}$ in the lungs and peak at $72 \mathrm{~h}$ in the MLN (1). HDM and other environmental factors trigger the airway epithelium to secrete chemokines and cytokines (61). Secretion of CCL2 will drive migration of monocytes toward the lungs (62), where they will differentiate into moDCs under the regulation of both CCL2 (1) and colony-stimulating factor 1 (23). MoDCs are efficient in antigen uptake; however, their capacity to drive T-cell proliferation is inferior to cDC2s. Instead, moDCs produce vast amounts of cytokines and chemokines essential for the recruitment and activation of Th2-cells upon HDM exposure (1) (Figure 2A). This indicates that moDCs are dispensable for Th2 differentiation but essential during the effector phase of asthma models, as depletion of $\mathrm{CD}_{1} 1 \mathrm{~b}^{+}$myeloid cells, which includes monocytes, during allergen challenge drastically reduces eosinophilia (63). Nevertheless, with high antigen dose, moDCs migrate toward the MLN and induce Th2 differentiation in the absence of cDCs upon exposure to HDM (1) or cockroach extract (64). Depletion of migratory cDCs enhances Th2 cell-mediated immune responses in an OVA-alum model (65). Furthermore, absence of Th2-cell-mediated immunity, due to the absence of DCs, can be reverted by an adoptive transfer of monocytes that differentiate into moDCs (66). Likewise, it was shown that systemic administration of BM-derived $\mathrm{CD} 11 \mathrm{~b}^{+}$cells efficiently induces Th2-mediated eosinophilic airway inflammation (67). This implicates that at high allergen concentration, moDCs can acquire migratory capacities, induce Th2 differentiation, and thereby drive Th2-mediated immune responses.

\section{MURINE pDCs}

\section{Development of pDCs}

Plasmacytoid DCs differentiate directly in the BM from CDPs (68). Differentiation of pDCs depends on Flt3L and signal transducer and activator of transcription 3 signaling, in combination with transcription factors, such as E2-2, IRF8, Ikaros, and PU.1, of which E2-2 is highly specific for pDC development (69-71) (Figure 1).

\section{Function of pDCs in Asthma}

Plasmacytoid DCs are essential for antiviral immune responses as they produce large amounts of interferon alpha (IFN- $\alpha$ ) after Toll-like receptor (TLR7) activation $(72,73)$. In comparison to other DC subsets, pDCs have a limited capacity to take up and present antigens $(1,19,74,75)$. pDCs have a tolerogenic function in asthma, as pDCs induce Treg cell differentiation $(76,77)$, and depletion of pDCs in Siglec-H-DTR mice increased the proliferation of antigen-specific $\mathrm{CD} 4^{+} \mathrm{T}$-cells (78). Increase in $\mathrm{pDC}$ 
numbers, as induced by Flt3L treatment, alleviate eosinophilic inflammation, which is reversed upon pDC depletion (79). Programmed death-ligand 1 (PD-L1) expression on pDCs is essential for their suppressive effect, as PD-L1-deficient pDCs could not alleviate allergic airway inflammation, whereas IDO or inducible T-cell costimulator ligand (ICOSL)-deficient pDCs could do so (79) (Figure 2A). Development of HDM-driven allergic asthma can be inhibited by adoptive transfer of pDCs from sensitized donors (80). Different pulmonary pDC subsets have been described, e.g., $\mathrm{CD} 8 \alpha^{-} \beta^{-}, \mathrm{CD} 8 \alpha^{+} \beta^{-}$, and $\mathrm{CD} 8 \alpha^{+} \beta^{+}$ pDCs (81). Only CD8 $\alpha^{+} \beta^{-}$pDCs and CD $8 \alpha^{+} \beta^{+}$pDCs have tolerogenic capacities, whereas $\mathrm{CD} 8 \alpha^{-} \beta^{-}$pDCs display more proinflammatory functions upon TLR7 and TLR9 stimulation (81). Specifically, CD $8 \alpha^{+} \beta^{+}$pDCs and $C D 8 \alpha^{+} \beta^{-}$pDCs have increased expression of retinal dehydrogenase leading to RA production, resulting in increased Treg differentiation (81).

Plasmacytoid DCs are essential for beneficial effects observed in immunotherapy via complement subunit C1q. Administration of $\mathrm{Clq}$ reduces airway hyperresponsiveness (AHR) and eosinophilia as efficiently as dexamethasone administration. pDC depletion abrogates the protective effect of $\mathrm{Clq}$ (82).

Viral infections are often detected during asthma exacerbations. Viral particles activate DC subsets via TLR7, and its expression was decreased in pDCs by allergic inflammation. TLR7-deficient mice displayed reduced IFN secretion, increased virus replication, and increased eosinophilic inflammation and AHR, indicating that impaired TLR7 expression on pDCs by allergic inflammation exaggerates asthma exacerbations (83). Furthermore, pDCs transferred from donors with a respiratory tract syncytial virus (RSV) infection did not provide protection from Th2-mediated inflammation as transferred pDCs from naïve mice did (80). CpG-maturated pDCs are well capable of protecting from eosinophilic inflammation (79), suggesting that altered activation of pDCs affects their function.

\section{HUMAN PULMONARY DC SUBSETS}

\section{Transcriptional Development of Human DCs}

In human lungs, three different DC subsets have been described, human DC1s, which express BDCA1/CD1c, DC2s, which expresses BDCA3/CD141 and pDCs, which express BDCA2/ CD123 (3, 4, 84). Gene expression profiles of human DC1s and DC2s revealed that human DC subsets resembled mouse $\mathrm{cDC} 1 \mathrm{~s}$ and cDC2s, respectively $(3,85-88)$. Development of human DCs is also highly dependent on Flt3L, as Flt3 $\mathrm{L}$ injection drastically increases the number of blood DCs of healthy volunteers (89). Similar to that in mice, differentiation of human pDCs is mediated by E2-2 (90), whereas $\mathrm{CDC} 1$ and $\mathrm{CDC} 2$ differentiation is controlled by BATF3 $(91)$ and IRF4 $(92,93)$, respectively.

\section{Location of Human DC Subsets in the Lungs}

$\mathrm{BDCA}^{+} \mathrm{CDC}^{2}$ s were increased in the airway epithelium of asthma patients that display a Th2 phenotype, whereas this was not observed in patients without a Th2 profile (94). DCs are increased in the outer wall of the large airways in patients who suffer from fatal asthma (95). These are likely moDCs, as they express XIIIa (95), a coagulation factor also expressed by macrophages in the skin (96). As both moDCs and macrophages are derived from monocytes this suggests an overlapping ontogeny. Unfortunately, lack of lung material containing epithelium and interstitium of both healthy controls and asthma patients complicates research on the localization of DC subset during steady state and in asthmatic lung. Recent consensus regarding universal markers that can identify DC subsets will facilitate the visualization of DC subsets in human organs (3).

\section{Function of Human DCs in Asthma}

Most studies that investigated human DC function, compared pDCs to myeloid DCs (mDCs) that include both DC1s and DC2s. Allergic asthmatics showed increased frequencies of DC1s and DC2s in peripheral blood (97), induced sputum and bronchoalveolar lavage (BAL) upon allergen inhalation compared to controls (98-100). After allergen inhalation, only DC2s migrated toward bronchial tissue (100). Allergen exposure increased the expression of thymic stromal lymphopoietin (TSLP)-receptor but not IL-33-receptor on cultured cDCs from CD $34^{+}$BM precursors, which are implicated as Th2 instructive cytokine receptors (100). Allergen inhalation induced expression of IL-25-receptor on both cDCs and pDC (101). The costimulatory molecule OX-40L and expression of Th2 chemoattractant CCL17 was higher on cDCs of patients with mild asthma than on cDCs of healthy controls (102) (Figure 2B). In patients who displayed high Th2-cell numbers, a large proportion of airway mucosal DC2s expressed FceRIa compared to Th2-cell low asthma patients (94) (Figure 2B). This is likely, as high IgE-levels are associated with high Th2-cell numbers, thereby suggesting that IgE increases FceRIa expression. IgE-bound antigens are rapidly internalized, processed, and presented by DCs to antigen-specific CD4 ${ }^{+} \mathrm{T}$-cells $(103,104)$. DC2s loaded with Dermatophagoides pteronyssinus antigen P1 (Der p1) allergen-IgE immune complexes induced IL-4 and lowered IFN- $\boldsymbol{\gamma}$-expression in in vitro cocultures with naive T-cells (105), indicating that allergen-IgE immune complexes promote Th2 differentiation (106). CD86 expression was higher on mDCs of asthmatic children than on mDCs of atopic children. Furthermore, upon LPS stimulation IL-6 production by mDCs of asthmatic children was decreased, compared with mDCs of atopic children (107). The numbers of IL12-producing mDCs were also lower in asthmatic children (108), indicating the presence of a Th2 promoting environment in asthmatic children. cDCs of allergic asthmatics induced increased Th2 differentiation upon stimulation with TSLP and Der $\mathrm{p}$ compared to cDCs of controls (109). TSLP-stimulated cDCs of allergic asthmatics and not of controls, induced IL-9 production and PU.1 expression, indicative of Th9 differentiation (109). When Th2 priming capacity of DC1s and DC2s from human blood and lungs were compared, both lung and blood DC1s were superior in Th2 differentiation (110). However, in this study, live-attenuated influenza virus was used to activate DC1s and DC2s, which primarily activates DC1s, as these induce antiviral immune responses (24). The expression of CD141, a marker for DC1s, is increased in blood leukocytes during acute asthma exacerbations on moDCs, 
but surprisingly not on DC1s (111). This indicates that DC1s or CD141 expression plays an important role in the pathogenesis of asthma. DC2s from allergic rhinitis patients efficiently prime Th2 differentiation (112) and express lower levels of ICOSL, compared to controls (Figure 2B). Blockade of ICOSL in DC2s of controls increases the production of Th2 cytokines, indicating that decreased ICOSL expression on DC2s promotes Th2 differentiation (113). Both human DC1s and DC2s induce Th2 cytokines; however, Th2 differentiation by $\mathrm{cDC} 1$ s was observed following exposure to live-attenuated viral particles (112). This implicated that during virus infections, $\mathrm{cDC} 1 \mathrm{~s}$ in asthmatics shift from promoting Th1 immune responses or maintaining tolerance toward a Th2-promoting phenotype.

Allergen inhalation increased pDCs numbers in the airway lumen $(98,114)$; however, variable results exist whether circulating pDCs differ between asthmatics and healthy individuals $(115,116)$. In a birth cohort, circulating pDCs predicted respiratory tract infections, wheezing, and asthma diagnosis by 5 years of age (117). pDCs of severe asthmatics also produced less IFN- $\alpha$ following influenza infection, than pDCs of healthy controls did (118) (Figure 2B). Single-cell analysis revealed that characterization of pDCs based on CD123 expression included DC precursors $(119,120)$. Therefore, these findings need to be revisited whether they truly induced by pDCs.

House dust mite activation of cultured moDCs of HDMallergic asthma patients expressed higher levels of human leukocyte antigen-D, induced more T-cell proliferation (121), and Th2 differentiation than control moDCs (122). When examining the frequency of $\mathrm{CD} 14^{+} / \mathrm{CD} 16^{+}$monocytes, conflicting results exist in severe asthmatics $(123,124)$. Monocytes of allergic patients showed increased IL-10 and decreased IL-12 production upon HDM and Der p1 stimulation, which enhanced Th2 differentiation (125). CD14 $/ \mathrm{CD} 16^{+}$monocytes of severe asthmatics display

\section{REFERENCES}

1. Plantinga M, Guilliams M, Vanheerswynghels M, Deswarte K, BrancoMadeira F, Toussaint W, et al. Conventional and monocyte-derived CD11b(+) dendritic cells initiate and maintain $\mathrm{T}$ helper 2 cell-mediated immunity to house dust mite allergen. Immunity (2013) 38(2):322-35. doi:10.1016/j. immuni.2012.10.016

2. Lambrecht BN, Hammad H. Lung dendritic cells: targets for therapy in allergic disease. Handb Exp Pharmacol (2009) 188:99-114. doi:10.1007/9783-540-71029-5_5

3. Guilliams M, Dutertre CA, Scott CL, McGovern N, Sichien D, Chakarov S, et al. Unsupervised high-dimensional analysis aligns dendritic cells across tissues and species. Immunity (2016) 45(3):669-84. doi:10.1016/j. immuni.2016.08.015

4. Guilliams M, Ginhoux F, Jakubzick C, Naik SH, Onai N, Schraml BU, et al. Dendritic cells, monocytes and macrophages: a unified nomenclature based on ontogeny. Nat Rev Immunol (2014) 14(8):571-8. doi:10.1038/nri3712

5. Jacquet A. Innate immune responses in house dust mite allergy. ISRN Allergy (2013) 2013:735031. doi:10.1155/2013/735031

6. Wang J-Y. The innate immune response in house dust mite-induced allergic inflammation. Allergy Asthma Immunol Res (2013) 5(2):68-74. doi:10.4168/ aair.2013.5.2.68

7. Kool M, van Loo G, Waelput W, De Prijck S, Muskens F, Sze M, et al. The ubiquitin-editing protein A20 prevents dendritic cell activation, recognition of apoptotic cells, and systemic autoimmunity. Immunity (2011) 35(1):82-96. doi:10.1016/j.immuni.2011.05.013 higher expression of protease activation receptor 2 (PAR-2) as compared to mild/moderate asthmatics (124) (Figure 2B). PAR-2-mediated activation of monocytes induces secretion of IL-1 $\beta$, IL-6, and IL-8 (126), indicating that activation via PAR-2 facilitates secretion of cytokines important for Th17-cell differentiation and neutrophil activation and attraction, which does not occur in mild/moderate asthmatics.

\section{CLINICAL IMPLICATIONS}

In conclusion, whereas in mice the function of different DC subsets in asthma pathogenesis is becoming more and more clear, there are no studies at present that compared the Th2or Th17-priming capacity of different human DC subsets in response to allergens. The limited number of DCs in peripheral blood and the difficulty to obtain lung or lung-draining lymph nodes hamper these studies. Current advances in single-cell analysis enable analysis of DC subsets and have already proven that more DC subsets and DC precursors can be found in peripheral blood $(119,120)$. Further research should provide insights into DC subset characteristics and function in asthmatics that display either a Th2, Th2/Th17, or Th17-mediated inflammation.

\section{AUTHOR CONTRIBUTIONS}

All authors listed have made a substantial, direct, and intellectual contribution to the work and approved it for publication.

\section{ACKNOWLEDGMENTS}

These studies were partly supported by Netherlands Lung Foundation (3.2.12.087, 4.2.13.054JO, and 9.2.15.065FE).

8. Naik SH, Sathe P, Park HY, MetcalfD, Proietto AI, Dakic A, et al. Development of plasmacytoid and conventional dendritic cell subtypes from single precursor cells derived in vitro and in vivo. Nat Immunol (2007) 8(11):1217-26. doi:10.1038/ni1522

9. Belz GT, Nutt SL. Transcriptional programming of the dendritic cell network. Nat Rev Immunol (2012) 12(2):101-13. doi:10.1038/nri3149

10. Grajales-Reyes GE, Iwata A, Albring J, Wu X, Tussiwand R, Kc W, et al. Batf3 maintains autoactivation of Irf8 for commitment of a CD8alpha(+) conventional DC clonogenic progenitor. Nat Immunol (2015) 16(7):708-17. doi:10.1038/ni.3197

11. Schlitzer A, Sivakamasundari V, Chen J, Sumatoh HR, Schreuder J, Lum J, et al. Identification of $\mathrm{CDC1}$ - and $\mathrm{CDC} 2$-committed DC progenitors reveals early lineage priming at the common DC progenitor stage in the bone marrow. Nat Immunol (2015) 16(7):718-28. doi:10.1038/ni.3200

12. Hettinger J, Richards DM, Hansson J, Barra MM, Joschko AC, Krijgsveld J, et al. Origin of monocytes and macrophages in a committed progenitor. Nat Immunol (2013) 14(8):821-30. doi:10.1038/ni.2638

13. Sathe P, Metcalf D, Vremec D, Naik SH, Langdon WY, Huntington ND, et al. Lymphoid tissue and plasmacytoid dendritic cells and macrophages do not share a common macrophage-dendritic cell-restricted progenitor. Immunity (2014) 41(1):104-15. doi:10.1016/j.immuni.2014.05.020

14. Sung SS, Fu SM, Rose CE Jr, Gaskin F, Ju ST, Beaty SR. A major lung CD103 (alphaE)-beta7 integrin-positive epithelial dendritic cell population expressing Langerin and tight junction proteins. J Immunol (2006) 176(4):2161-72. doi:10.4049/jimmunol.176.4.2161

15. von Garnier C, Filgueira L, Wikstrom M, Smith M, Thomas JA, Strickland DH, et al. Anatomical location determines the distribution and function of 
dendritic cells and other APCs in the respiratory tract. J Immunol (2005) 175(3):1609-18. doi:10.4049/jimmunol.175.3.1609

16. Thornton EE, Looney MR, Bose O, Sen D, Sheppard D, Locksley R, et al. Spatiotemporally separated antigen uptake by alveolar dendritic cells and airway presentation to T cells in the lung. J Exp Med (2012) 209(6):1183-99. doi:10.1084/jem.20112667

17. Rodero MP, Poupel L, Loyher PL, Hamon P, Licata F, Pessel C, et al. Immune surveillance of the lung by migrating tissue monocytes. Elife (2015) 4:e07847. doi:10.7554/eLife.07847

18. Sauter KA, Pridans C, Sehgal A, Bain CC, Scott C, Moffat L, et al. The MacBlue binary transgene (csf1r-gal4VP16/UAS-ECFP) provides a novel marker for visualisation of subsets of monocytes, macrophages and dendritic cells and responsiveness to CSF1 administration. PLoS One (2014) 9(8):e105429. doi:10.1371/journal.pone.0105429

19. de Heer HJ, Hammad H, Soullié T, Hijdra D, Vos N, Willart MA, et al. Essential role of lung plasmacytoid dendritic cells in preventing asthmatic reactions to harmless inhaled antigen. JExp Med (2004) 200(1):89-98. doi:10.1084/jem.20040035

20. Sichien D, Scott CL, Martens L, Vanderkerken M, Van Gassen S, Plantinga M, et al. IRF8 transcription factor controls survival and function of terminally differentiated conventional and plasmacytoid dendritic cells, respectively. Immunity (2016) 45(3):626-40. doi:10.1016/j.immuni.2016.08.013

21. Hildner K, Edelson BT, Purtha WE, Diamond M, Matsushita H, Kohyama M, et al. Batf3 deficiency reveals a critical role for CD8alpha+ dendritic cells in cytotoxic T cell immunity. Science (2008) 322(5904):1097-100. doi:10.1126/ science.1164206

22. Jackson JT, Hu Y, Liu R, Masson F, D’Amico A, Carotta S, et al. Id2 expression delineates differential checkpoints in the genetic program of CD8alpha+ and CD103+ dendritic cell lineages. EMBO J (2011) 30(13):2690-704. doi:10.1038/emboj.2011.163

23. Ginhoux F, Liu K, Helft J, Bogunovic M, Greter M, Hashimoto D, et al. The origin and development of nonlymphoid tissue CD103+ DCs. J Exp Med (2009) 206(13):3115-30. doi:10.1084/jem.20091756

24. GeurtsvanKessel CH, Willart MA, van Rijt LS, Muskens F, Kool M, Baas C, et al. Clearance of influenza virus from the lung depends on migratory langerin(+)CD11b(-) but not plasmacytoid dendritic cells. J Exp Med (2008) 205(7):1621-34. doi:10.1084/jem.20071365

25. Fuertes MB, Kacha AK, Kline J, Woo SR, Kranz DM, Murphy KM, et al. Host type I IFN signals are required for antitumor CD8+ T cell responses through CD8\{alpha\}+ dendritic cells. J Exp Med (2011) 208(10):2005-16. doi:10.1084/jem.20101159

26. Khare A, Krishnamoorthy N, Oriss TB, Fei M, Ray P, Ray A. Cutting edge: inhaled antigen upregulates retinaldehyde dehydrogenase in lung CD103(+) but not plasmacytoid dendritic cells to induce Foxp3 de novo in CD4(+) $\mathrm{T}$ cells and promote airway tolerance. JImmunol (2013) 191(1):25-9. doi:10.4049/jimmunol.1300193

27. Nakano H, Free ME, Whitehead GS, Maruoka S, Wilson RH, Nakano K, et al. Pulmonary CD103(+) dendritic cells prime $\mathrm{Th} 2$ responses to inhaled allergens. Mucosal Immunol (2012) 5(1):53-65. doi:10.1038/mi.2011.47

28. Khare A, Chakraborty K, Raundhal M, Ray P, Ray A. Cutting edge: dual function of PPARgamma in CD11c+ cells ensures immune tolerance in the airways. J Immunol (2015) 195(2):431-5. doi:10.4049/jimmunol.1500474

29. Bernatchez E, Gold MJ, Langlois A, Lemay AM, Brassard J, Flamand N, et al. Pulmonary CD103 expression regulates airway inflammation in asthma. Am J Physiol Lung Cell Mol Physiol (2015) 308(8):L816-26. doi:10.1152/ ajplung.00319.2014

30. Everts B, Tussiwand R, Dreesen L, Fairfax KC, Huang SC, Smith AM, et al. Migratory CD103+ dendritic cells suppress helminth-driven type $2 \mathrm{immu}-$ nity through constitutive expression of IL-12.J Exp Med (2016) 213(1):35-51. doi:10.1084/jem.20150235

31. Engler DB, Reuter S, van Wijck Y, Urban S, Kyburz A, Maxeiner J, et al. Effective treatment of allergic airway inflammation with Helicobacter pylori immunomodulators requires BATF3-dependent dendritic cells and IL-10. Proc Natl Acad Sci U S A (2014) 111(32):11810-5. doi:10.1073/pnas.1410579111

32. Fear VS, Lai SP, Zosky GR, Perks KL, Gorman S, Blank F, et al. A pathogenic role for the integrin CD103 in experimental allergic airways disease. Physiol Rep (2016) 4(21):e13021. doi:10.14814/phy2.13021

33. Agace WW, Higgins JM, Sadasivan B, Brenner MB, Parker CM. T-lymphocyteepithelial-cell interactions: integrin alpha(E)(CD103)beta(7), LEEP-CAM and chemokines. Curr Opin Cell Biol (2000) 12(5):563-8. doi:10.1016/ S0955-0674(00)00132-0

34. Zelante T, Wong AY, Ping TJ, Chen J, Sumatoh HR, Viganò E, et al. CD103(+) dendritic cells control Th17 cell function in the lung. Cell Rep (2015) 12(11):1789-801. doi:10.1016/j.celrep.2015.08.030

35. Desch AN, Randolph GJ, Murphy K, Gautier EL, Kedl RM, Lahoud MH, et al. CD103+ pulmonary dendritic cells preferentially acquire and present apoptotic cell-associated antigen. J Exp Med (2011) 208(9):1789-97. doi:10.1084/ jem. 20110538

36. Zahner SP, Kel JM, Martina CA, Brouwers-Haspels I, van Roon MA, Clausen BE. Conditional deletion of TGF-betaR1 using Langerin-Cre mice results in Langerhans cell deficiency and reduced contact hypersensitivity. J Immunol (2011) 187(10):5069-76. doi:10.4049/jimmunol.1101880

37. Wu L, D’Amico A, Winkel KD, Suter M, Lo D, Shortman K. RelB is essential for the development of myeloid-related CD8alpha- dendritic cells but not of lymphoid-related CD8alpha+ dendritic cells. Immunity (1998) 9(6):839-47. doi:10.1016/S1074-7613(00)80649-4

38. Guerriero A, Langmuir PB, Spain LM, Scott EW. PU.1 is required for myeloid-derived but not lymphoid-derived dendritic cells. Blood (2000) 95(3):879-85

39. Caton ML, Smith-Raska MR, Reizis B. Notch-RBP-J signaling controls the homeostasis of CD8- dendritic cells in the spleen. J Exp Med (2007) 204(7):1653-64. doi:10.1084/jem.20062648

40. Lewis KL, Caton ML, Bogunovic M, Greter M, Grajkowska LT, Ng D, et al. Notch2 receptor signaling controls functional differentiation of dendritic cells in the spleen and intestine. Immunity (2011) 35(5):780-91. doi:10.1016/j. immuni.2011.08.013

41. Satpathy AT, Briseño CG, Lee JS, Ng D, Manieri NA, Kc W, et al. Notch2dependent classical dendritic cells orchestrate intestinal immunity to attaching-and-effacing bacterial pathogens. Nat Immunol (2013) 14(9):937-48. doi: $10.1038 /$ ni.2679

42. Schlitzer A, McGovern N, Teo P, Zelante T, Atarashi K, Low D, et al. IRF4 transcription factor-dependent $\mathrm{CD} 11 \mathrm{~b}+$ dendritic cells in human and mouse control mucosal IL-17 cytokine responses. Immunity (2013) 38(5):970-83. doi:10.1016/j.immuni.2013.04.011

43. Suzuki S, Honma K, Matsuyama T, Suzuki K, Toriyama K, Akitoyo I, et al. Critical roles of interferon regulatory factor 4 in CD11bhighCD8alphadendritic cell development. Proc Natl Acad Sci U S A (2004) 101(24):8981-6. doi:10.1073/pnas.0402139101

44. Tamura T, Tailor P, Yamaoka K, Kong HJ, Tsujimura H, O'Shea JJ, et al. IFN regulatory factor- 4 and -8 govern dendritic cell subset development and their functional diversity. J Immunol (2005) 174(5):2573-81. doi:10.4049/ jimmunol.174.5.2573

45. Furuhashi K, Suda T, Hasegawa H, Suzuki Y, Hashimoto D, Enomoto N, et al. Mouse lung CD103+ and CD11bhigh dendritic cells preferentially induce distinct CD4+ T-cell responses. Am J Respir Cell Mol Biol (2012) 46(2):165-72. doi:10.1165/rcmb.2011-0070OC

46. Raymond M, Rubio M, Fortin G, Shalaby KH, Hammad H, Lambrecht BN, et al. Selective control of SIRP-alpha-positive airway dendritic cell trafficking through $\mathrm{CD} 47$ is critical for the development of $\mathrm{T}(\mathrm{H}) 2$-mediated allergic inflammation. J Allergy Clin Immunol (2009) 124(6):1333-42.e1. doi:10.1016/j.jaci.2009.07.021

47. Persson EK, Uronen-Hansson H, Semmrich M, Rivollier A, Hägerbrand K, Marsal J, et al. IRF4 transcription-factor-dependent CD103(+)CD11b(+) dendritic cells drive mucosal $\mathrm{T}$ helper 17 cell differentiation. Immunity (2013) 38(5):958-69. doi:10.1016/j.immuni.2013.03.009

48. Norimoto A, Hirose K, Iwata A, Tamachi T, Yokota M, Takahashi K, et al. Dectin-2 promotes house dust mite-induced T helper type 2 and type 17 cell differentiation and allergic airway inflammation in mice. Am J Respir Cell Mol Biol (2014) 51(2):201-9. doi:10.1165/rcmb.2013-0522OC

49. Barrett NA, Maekawa A, Rahman OM, Austen KF, Kanaoka Y. Dectin-2 recognition of house dust mite triggers cysteinyl leukotriene generation by dendritic cells. J Immunol (2009) 182(2):1119-28. doi:10.4049/ jimmunol.182.2.1119

50. Gao Y, Nish SA, Jiang R, Hou L, Licona-Limón P, Weinstein JS, et al. Control of $\mathrm{T}$ helper 2 responses by transcription factor IRF4-dependent dendritic cells. Immunity (2013) 39(4):722-32. doi:10.1016/j.immuni.2013.08.028

51. Deckers J, Sichien D, Plantinga M, Van Moorleghem J, Vanheerswynghels M, Hoste E, et al. Epicutaneous sensitization to house dust mite allergen requires 
IRF4-dependent dermal dendritic cells. J Allergy Clin Immunol (2017). doi:10.1016/j.jaci.2016.12.970

52. Williams JW, Tjota MY, Clay BS, Vander Lugt B, Bandukwala HS, Hrusch CL, et al. Transcription factor IRF4 drives dendritic cells to promote Th2 differentiation. Nat Commun (2013) 4:2990. doi:10.1038/ncomms3990

53. Ito T, Hirose K, Norimoto A, Tamachi T, Yokota M, Saku A, et al. Dectin-1 plays an important role in house dust mite-induced allergic airway inflammation through the activation of CD11b+ dendritic cells. J Immunol (2017) 198(1):61-70. doi:10.4049/jimmunol.1502393

54. Han J, Dakhama A, Jia Y, Wang M, Zeng W, Takeda K, et al. Responsiveness to respiratory syncytial virus in neonates is mediated through thymic stromal lymphopoietin and OX40 ligand. JAllergy Clin Immunol (2012) 130(5):1175-86.e9. doi:10.1016/j.jaci.2012.08.033

55. de Kleer IM, Kool M, de Bruijn MJ, Willart M, van Moorleghem J, Schuijs MJ, et al. Perinatal activation of the interleukin-33 pathway promotes type 2 immunity in the developing lung. Immunity (2016) 45(6):1285-98. doi:10.1016/j.immuni.2016.10.031

56. Geissmann F, Jung S, Littman DR. Blood monocytes consist of two principal subsets with distinct migratory properties. Immunity (2003) 19(1):71-82. doi:10.1016/S1074-7613(03)00174-2

57. Jakubzick C, Gautier EL, Gibbings SL, Sojka DK, Schlitzer A, Johnson TE, et al. Minimal differentiation of classical monocytes as they survey steady-state tissues and transport antigen to lymph nodes. Immunity (2013) 39(3):599-610. doi:10.1016/j.immuni.2013.08.007

58. Yona S, Kim KW, Wolf Y, Mildner A, Varol D, Breker M, et al. Fate mapping reveals origins and dynamics of monocytes and tissue macrophages under homeostasis. Immunity (2013) 38(1):79-91. doi:10.1016/j. immuni.2012.12.001

59. Auffray C, Fogg D, Garfa M, Elain G, Join-Lambert O, Kayal S, et al. Monitoring of blood vessels and tissues by a population of monocytes with patrolling behavior. Science (2007) 317(5838):666-70. doi:10.1126/ science. 1142883

60. Jakubzick C, Tacke F, Ginhoux F, Wagers AJ, van Rooijen N, Mack M, et al. Blood monocyte subsets differentially give rise to CD103+ and CD103pulmonary dendritic cell populations. J Immunol (2008) 180(5):3019-27. doi:10.4049/jimmunol.180.5.3019

61. Lambrecht BN, Hammad $\mathrm{H}$. The immunology of asthma. Nat Immunol (2015) 16(1):45-56. doi:10.1038/ni.3049

62. Robays LJ, Maes T, Lebecque S, Lira SA, Kuziel WA, Brusselle GG, et al. Chemokine receptor CCR2 but not CCR5 or CCR6 mediates the increase in pulmonary dendritic cells during allergic airway inflammation. J Immunol (2007) 178(8):5305-11. doi:10.4049/jimmunol.178.8.5305

63. Medoff BD, Seung E, Hong S, Thomas SY, Sandall BP, Duffield JS, et al. $\mathrm{CD} 11 \mathrm{~b}+$ myeloid cells are the key mediators of Th2 cell homing into the airway in allergic inflammation. J Immunol (2009) 182(1):623-35. doi:10.4049/ jimmunol.182.1.623

64. Walzer T, Brawand P, Swart D, Tocker J, De Smedt T. No defect in T-cell priming, secondary response, or tolerance induction in response to inhaled antigens in Fms-like tyrosine kinase 3 ligand-deficient mice. J Allergy Clin Immunol (2005) 115(1):192-9. doi:10.1016/j.jaci.2004.08.046

65. Grinnan D, Sung SS, Dougherty JA, Knowles AR, Allen MB, Rose CE III, et al. Enhanced allergen-induced airway inflammation in paucity of lymph node T cell (plt) mutant mice. J Allergy Clin Immunol (2006) 118(6):1234-41. doi:10.1016/j.jaci.2006.07.036

66. Kool M, Soullié T, van Nimwegen M, Willart MA, Muskens F, Jung S, et al. Alum adjuvant boosts adaptive immunity by inducing uric acid and activating inflammatory dendritic cells. J Exp Med (2008) 205(4):869-82. doi:10.1084/jem.20071087

67. Cruz JL, Pérez-Girón JV, Lüdtke A, Gómez-Medina S, Ruibal P, Idoyaga J, et al. Monocyte-derived dendritic cells enhance protection against secondary influenza challenge by controlling the switch in CD8+ T-cell immunodominance. Eur J Immunol (2017) 47(2):345-52. doi:10.1002/eji.201646523

68. Gilliet M, Boonstra A, Paturel C, Antonenko S, Xu XL, Trinchieri G, et al. The development of murine plasmacytoid dendritic cell precursors is differentially regulated by FLT3-ligand and granulocyte/macrophage colony-stimulating factor. J Exp Med (2002) 195(7):953-8. doi:10.1084/jem.20020045

69. Esashi E, Watowich SS. Dendritic cells: transcriptional control of plasmacytoid dendritic cell development by E2-2. Immunol Cell Biol (2009) 87(1):1-2. doi:10.1038/icb.2008.93
70. Li HS, Yang CY, Nallaparaju KC, Zhang H, Liu YJ, Goldrath AW, et al. The signal transducers STAT5 and STAT3 control expression of Id2 and E2-2 during dendritic cell development. Blood (2012) 120(22):4363-73. doi:10.1182/ blood-2012-07-441311

71. Merad M, Sathe P, Helft J, Miller J, Mortha A. The dendritic cell lineage: ontogeny and function of dendritic cells and their subsets in the steady state and the inflamed setting. Annu Rev Immunol (2013) 31:563-604. doi:10.1146/ annurev-immunol-020711-074950

72. Grayson MH, Ramos MS, Rohlfing MM, Kitchens R, Wang HD, Gould A, et al. Controls for lung dendritic cell maturation and migration during respiratory viral infection. JImmunol (2007) 179(3):1438-48. doi:10.4049/jimmunol.179.3.1438

73. Smit JJ, Rudd BD, Lukacs NW. Plasmacytoid dendritic cells inhibit pulmonary immunopathology and promote clearance of respiratory syncytial virus. J Exp Med (2006) 203(5):1153-9. doi:10.1084/jem.20052359

74. Lewkowich IP, Lajoie S, Clark JR, Herman NS, Sproles AA, Wills-Karp M. Allergen uptake, activation, and IL-23 production by pulmonary myeloid DCs drives airway hyperresponsiveness in asthma-susceptible mice. PLoS One (2008) 3(12):e3879. doi:10.1371/journal.pone.0003879

75. Kool M, Geurtsvankessel C, Muskens F, Madeira FB, van Nimwegen M, Kuipers $\mathrm{H}$, et al. Facilitated antigen uptake and timed exposure to TLR ligands dictate the antigen-presenting potential of plasmacytoid DCs. J Leukoc Biol (2011) 90(6):1177-90. doi:10.1189/jlb.0610342

76. Oriss TB, Ostroukhova M, Seguin-Devaux C, Dixon-McCarthy B, Stolz DB, Watkins SC, et al. Dynamics of dendritic cell phenotype and interactions with CD4+ T cells in airway inflammation and tolerance. J Immunol (2005) 174(2):854-63. doi:10.4049/jimmunol.174.2.854

77. Lewkowich IP, Herman NS, Schleifer KW, Dance MP, Chen BL, Dienger KM, et al. CD4+CD25+ T cells protect against experimentally induced asthma and alter pulmonary dendritic cell phenotype and function. J Exp Med (2005) 202(11):1549-61. doi:10.1084/jem.20051506

78. Takagi H, Fukaya T, Eizumi K, Sato Y, Sato K, Shibazaki A, et al. Plasmacytoid dendritic cells are crucial for the initiation of inflammation and T cell immunity in vivo. Immunity (2011) 35(6):958-71. doi:10.1016/j. immuni.2011.10.014

79. Kool M, van Nimwegen M, Willart MA, Muskens F, Boon L, Smit JJ, et al. An anti-inflammatory role for plasmacytoid dendritic cells in allergic airway inflammation. J Immunol (2009) 183(2):1074-82. doi:10.4049/ jimmunol.0900471

80. Tsuchida T, Matsuse H, Fukahori S, Kawano T, Tomari S, Fukushima C, et al. Effect of respiratory syncytial virus infection on plasmacytoid dendritic cell regulation of allergic airway inflammation. Int Arch Allergy Immunol (2012) 157(1):21-30. doi:10.1159/000324676

81. Lombardi V, Speak AO, Kerzerho J, Szely N, Akbari O. CD8alpha(+)beta(-) and CD8alpha(+)beta(+) plasmacytoid dendritic cells induce Foxp3(+) regulatory T cells and prevent the induction of airway hyper-reactivity. Mucosal Immunol (2012) 5(4):432-43. doi:10.1038/mi.2012.20

82. Mascarell L, Airouche S, Berjont N, Gary C, Gueguen C, Fourcade G, et al. The regulatory dendritic cell marker $\mathrm{Clq}$ is a potent inhibitor of allergic inflammation. Mucosal Immunol (2017) 10(3):695-704. doi:10.1038/mi.2016.87

83. Hatchwell L, Collison A, Girkin J, Parsons K, Li J, Zhang J, et al. Toll-like receptor 7 governs interferon and inflammatory responses to rhinovirus and is suppressed by IL-5-induced lung eosinophilia. Thorax (2015) 70(9):854-61. doi:10.1136/thoraxjnl-2014-205465

84. Demedts IK, Brusselle GG, Vermaelen KY, Pauwels RA. Identification and characterization of human pulmonary dendritic cells. Am J Respir Cell Mol Biol (2005) 32(3):177-84. doi:10.1165/rcmb.2004-0279OC

85. Robbins SH, Walzer T, Dembélé D, Thibault C, Defays A, Bessou G, et al. Novel insights into the relationships between dendritic cell subsets in human and mouse revealed by genome-wide expression profiling. Genome Biol (2008) 9(1):R17. doi:10.1186/gb-2008-9-1-r17

86. Haniffa M, Shin A, Bigley V, McGovern N, Teo P, See P, et al. Human tissues contain CD141hi cross-presenting dendritic cells with functional homology to mouse CD103+ nonlymphoid dendritic cells. Immunity (2012) 37(1):60-73. doi:10.1016/j.immuni.2012.04.012

87. Bachem A, Güttler S, Hartung E, Ebstein F, Schaefer M, Tannert A, et al. Superior antigen cross-presentation and XCR1 expression define human CD11c+CD141+ cells as homologues of mouse CD8+ dendritic cells. J Exp Med (2010) 207(6):1273-81. doi:10.1084/jem.20100348 
88. Poulin LF, Salio M, Griessinger E, Anjos-Afonso F, Craciun L, Chen JL, et al. Characterization of human DNGR-1+ BDCA3+ leukocytes as putative equivalents of mouse CD8alpha+ dendritic cells. J Exp Med (2010) 207(6):1261-71. doi:10.1084/jem.20092618

89. Pulendran B, Banchereau J, Burkeholder S, Kraus E, Guinet E, Chalouni C, et al. Flt3-ligand and granulocyte colony-stimulating factor mobilize distinct human dendritic cell subsets in vivo. J Immunol (2000) 165(1):566-72. doi:10.4049/jimmunol.165.1.566

90. Cisse B, Caton ML, Lehner M, Maeda T, Scheu S, Locksley R, et al. Transcription factor E2-2 is an essential and specific regulator of plasmacytoid dendritic cell development. Cell (2008) 135(1):37-48. doi:10.1016/j. cell.2008.09.016

91. Poulin LF, Reyal Y, Uronen-Hansson H, Schraml BU, Sancho D, Murphy KM, et al. DNGR-1 is a specific and universal marker of mouse and human Batf3-dependent dendritic cells in lymphoid and nonlymphoid tissues. Blood (2012) 119(25):6052-62. doi:10.1182/blood-2012-01-406967

92. Schlitzer A, Ginhoux F. DNGR-ing the dendritic cell lineage. EMBO Rep (2013) 14(10):850-1. doi:10.1038/embor.2013.129

93. Watchmaker PB, Lahl K, Lee M, Baumjohann D, Morton J, Kim SJ, et al. Comparative transcriptional and functional profiling defines conserved programs of intestinal DC differentiation in humans and mice. Nat Immunol (2014) 15(1):98-108. doi:10.1038/ni.2768

94. Greer AM, Matthay MA, Kukreja J, Bhakta NR, Nguyen CP, Wolters PJ, et al. Accumulation of BDCA1(+) dendritic cells in interstitial fibrotic lung diseases and Th2-high asthma. PLoS One (2014) 9(6):e99084. doi:10.1371/ journal.pone.0099084

95. Cagnoni EF, Ferreira DS, Ferraz da Silva LF, Nicoletti Carvalho Petry AL, Gomes dos Santos AB, Rodrigues Medeiros MC, et al. Bronchopulmonary lymph nodes and large airway cell trafficking in patients with fatal asthma. J Allergy Clin Immunol (2015) 135(5):e1-9. doi:10.1016/j.jaci.2014.08.021

96. Töröcsik D, Bárdos H, Hatalyák Z, Dezső B, Losonczy G, Paragh L, et al. Detection of factor XIII-A is a valuable tool for distinguishing dendritic cells and tissue macrophages in granuloma annulare and necrobiosis lipoidica. J Eur Acad Dermatol Venereol (2014) 28(8):1087-96. doi:10.1111/jdv.12290

97. Hayashi Y, Ishii Y, Hata-Suzuki M, Arai R, Chibana K, Takemasa A, et al. Comparative analysis of circulating dendritic cell subsets in patients with atopic diseases and sarcoidosis. Respir Res (2013) 14:29. doi:10.1186/ 1465-9921-14-29

98. Dua B, Watson RM, Gauvreau GM, O’Byrne PM. Myeloid and plasmacytoid dendritic cells in induced sputum after allergen inhalation in subjects with asthma. J Allergy Clin Immunol (2010) 126(1):133-9. doi:10.1016/j. jaci.2010.04.006

99. Dua B, Tang W, Watson R, Gauvreau G, O’Byrne PM. Myeloid dendritic cells type 2 after allergen inhalation in asthmatic subjects. Clin Exp Allergy (2014) 44(7):921-9. doi:10.1111/cea.12297

100. El-Gammal A, Oliveria JP, Howie K, Watson R, Mitchell P, Chen R, et al. Allergen-induced changes in bone marrow and airway dendritic cells in subjects with asthma. Am J Respir Crit Care Med (2016) 194(2):169-77. doi:10.1164/rccm.201508-1623OC

101. Tworek D, Smith SG, Salter BM, Baatjes AJ, Scime T, Watson R, et al. IL25 receptor expression on airway dendritic cells after allergen challenge in subjects with asthma. Am J Respir Crit Care Med (2016) 193(9):957-64. doi:10.1164/rccm.201509-17510C

102. Bleck B, Kazeros A, Bakal K, Garcia-Medina L, Adams A, Liu M, et al. Coexpression of type 2 immune targets in sputum-derived epithelial and dendritic cells from asthmatic subjects. J Allergy Clin Immunol (2015) 136(3):619-27.e5. doi:10.1016/j.jaci.2014.12.1950

103. Maurer D, Ebner C, Reininger B, Fiebiger E, Kraft D, Kinet JP, et al. The high affinity IgE receptor (Fc epsilon RI) mediates IgE-dependent allergen presentation. J Immunol (1995) 154(12):6285-90.

104. Maurer D, Fiebiger E, Reininger B, Ebner C, Petzelbauer P, Shi GP, et al. Fc epsilon receptor I on dendritic cells delivers IgE-bound multivalent antigens into a cathepsin S-dependent pathway of MHC class II presentation. J Immunol (1998) 161(6):2731-9.

105. Sharquie IK, Al-Ghouleh A, Fitton P, Clark MR, Armour KL, Sewell HF, et al. An investigation into IgE-facilitated allergen recognition and presentation by human dendritic cells. BMC Immunol (2013) 14:54. doi:10.1186/1471-2172-14-54
106. Shin JS, Greer AM. The role of FcepsilonRI expressed in dendritic cells and monocytes. Cell Mol Life Sci (2015) 72(12):2349-60. doi:10.1007/ s00018-015-1870-x

107. Kaario H, Nieminen JK, Karvonen AM, Huttunen K, Schröder PC, Vaarala O, et al. Circulating dendritic cells, farm exposure and asthma at early age. Scand J Immunol (2016) 83(1):18-25. doi:10.1111/sji.12389

108. Hagendorens MM, Ebo DG, Bridts CH, De Clerck LS, Stevens WJ. Flow cytometrical determination of regulatory cytokines (IL-10, IL-12) and circulating dendritic cell cytokines in allergic asthmatic children. Cytokine (2004) 26(2):82-8. doi:10.1016/j.cyto.2004.01.001

109. Froidure A, Shen C, Gras D, Van Snick J, Chanez P, Pilette C. Myeloid dendritic cells are primed in allergic asthma for thymic stromal lymphopoietinmediated induction of Th2 and Th9 responses. Allergy (2014) 69(8):1068-76. doi:10.1111/all.12435

110. Yu CI, Becker C, Metang P, Marches F, Wang Y, Toshiyuki H, et al. Human CD141+ dendritic cells induce CD4+ T cells to produce type 2 cytokines. J Immunol (2014) 193(9):4335-43. doi:10.4049/jimmunol.1401159

111. Yerkovich ST, Roponen M, Smith ME, McKenna K, Bosco A, Subrata LS, et al. Allergen-enhanced thrombomodulin (blood dendritic cell antigen 3, CD141) expression on dendritic cells is associated with a TH2-skewed immune response. JAllergy Clin Immunol (2009) 123(1):209-16.e4. doi:10.1016/j.jaci.2008.09.009

112. Pilette C, Jacobson MR, Ratajczak C, Detry B, Banfield G, VanSnick J, et al. Aberrant dendritic cell function conditions Th2-cell polarization in allergic rhinitis. Allergy (2013) 68(3):312-21. doi:10.1111/all.12090

113. Shen C, Hupin C, Froidure A, Detry B, Pilette C. Impaired ICOSL in human myeloid dendritic cells promotes Th2 responses in patients with allergic rhinitis and asthma. Clin Exp Allergy (2014) 44(6):831-41. doi:10.1111/ cea. 12308

114. Bratke K, Lommatzsch M, Julius P, Kuepper M, Kleine HD, Luttmann W, et al. Dendritic cell subsets in human bronchoalveolar lavage fluid after segmental allergen challenge. Thorax (2007) 62(2):168-75. doi:10.1136/ thx.2006.067793

115. Spears M, McSharry C, Donnelly I, Jolly L, Brannigan M, Thomson J, et al. Peripheral blood dendritic cell subtypes are significantly elevated in subjects with asthma. Clin Exp Allergy (2011) 41(5):665-72. doi:10.1111/ j.1365-2222.2010.03692.x

116. Wright AK, Mistry V, Richardson M, Shelley M, Thornton T, Terry S, et al. Toll-like receptor 9 dependent interferon-alpha release is impaired in severe asthma but is not associated with exacerbation frequency. Immunobiology (2015) 220(7):859-64. doi:10.1016/j.imbio.2015.01.005

117. Upham JW, Zhang G, Rate A, Yerkovich ST, Kusel M, Sly PD, et al. Plasmacytoid dendritic cells during infancy are inversely associated with childhood respiratory tract infections and wheezing. J Allergy Clin Immunol (2009) 124(4):707-13.e2. doi:10.1016/j.jaci.2009.07.009

118. Gill MA, Bajwa G, George TA, Dong CC, Dougherty II, Jiang N, et al. Counterregulation between the FcepsilonRI pathway and antiviral responses in human plasmacytoid dendritic cells. J Immunol (2010) 184(11):5999-6006. doi:10.4049/jimmunol.0901194

119. Villani AC, Satija R, Reynolds G, Sarkizova S, Shekhar K, Fletcher J, et al. Single-cell RNA-seq reveals new types of human blood dendritic cells, monocytes, and progenitors. Science (2017) 356(6335):eaah4573. doi:10.1126/ science.aah4573

120. See P, Dutertre CA, Chen J, Günther P, McGovern N, Irac SE, et al. Mapping the human DC lineage through the integration of high-dimensional techniques. Science (2017) 356:eaag3009. doi:10.1126/science.aag3009

121. van den Heuvel MM, Vanhee DD, Postmus PE, Hoefsmit EC, Beelen RH. Functional and phenotypic differences of monocyte-derived dendritic cells from allergic and nonallergic patients. J Allergy Clin Immunol (1998) 101 (1 Pt 1):90-5. doi:10.1016/S0091-6749(98)70198-8

122. Hammad H, Charbonnier AS, Duez C, Jacquet A, Stewart GA, Tonnel AB, et al. Th2 polarization by Der p 1 - pulsed monocyte-derived dendritic cells is due to the allergic status of the donors. Blood (2001) 98(4):1135-41. doi:10.1182/blood.V98.4.1135

123. Moniuszko M, Bodzenta-Lukaszyk A, Kowal K, Lenczewska D, Dabrowska M. Enhanced frequencies of CD14++CD16+, but not CD14+CD16+, peripheral blood monocytes in severe asthmatic patients. Clin Immunol (2009) 130(3):338-46. doi:10.1016/j.clim.2008.09.011 
124. Shrestha Palikhe N, Nahirney D, Laratta C, Gandhi VD, Vethanayagam D, Bhutani $\mathrm{M}$, et al. Increased protease-activated receptor-2 (PAR-2) expression on CD14++CD16+ peripheral blood monocytes of patients with severe asthma. PLoSOne (2015) 10(12):e0144500. doi:10.1371/journal.pone.0144500

125. Tomita K, Lim S, Hanazawa T, Usmani O, Stirling R, Chung KF, et al. Attenuated production of intracellular IL-10 and IL-12 in monocytes from patients with severe asthma. Clin Immunol (2002) 102(3):258-66. doi:10.1006/clim.2001.5176

126. Johansson U, Lawson C, Dabare M, Syndercombe-Court D, Newland AC, Howells GL, et al. Human peripheral blood monocytes express protease receptor-2 and respond to receptor activation by production of IL-6, IL-8, and IL-1\{beta\}. J Leukoc Biol (2005) 78(4):967-75. doi:10.1189/jlb.0704422
Conflict of Interest Statement: The authors declare that the research was conducted in the absence of any commercial or financial relationships that could be construed as a potential conflict of interest.

Copyright (c) 2017 Vroman, Hendriks and Kool. This is an open-access article distributed under the terms of the Creative Commons Attribution License (CC BY). The use, distribution or reproduction in other forums is permitted, provided the original author(s) or licensor are credited and that the original publication in this journal is cited, in accordance with accepted academic practice. No use, distribution or reproduction is permitted which does not comply with these terms. 